\title{
PENGARUH PERPUTARAN KAS DAN PERPUTARAN PIUTANG TERHADAP TINGKAT LIKUIDITAS PADA PT CITRA BATAM MILLENIUM
}

\author{
Juliana $^{1 *}$, Handra Tipa ${ }^{2}$ \\ ${ }^{1}$ Program Studi Akuntansi, Universitas Putera Batam \\ email: juli88819@gmail.com \\ ${ }^{2}$ Program Studi Akuntansi, Universitas Putera Batam \\ email: handratipa@gmail.com
}

\begin{abstract}
Companies that cannot control liquidity can lose the trust of external companies and distributors. Company liquidity can reflect the company's ability to repay business debt. The main objective of this research is to see whether there is a significant influence between cash turnover and accounts receivable turnover, both partially and simultaneously on the level of liquidity. The sample collection technique uses purposive sampling by determining certain weighted value samples so that the data used have a more representative value and the sample can represent the entire population. In this study using quantitative data in the form of secondary data sources by collecting company report data from 2014 to 2018 in 60 population samples. Researchers used multiple linear regression data analysis methods in order to produce data processing in the form of tables and graphs and conclusions. The results of the SPSS program in study showed partially cash turnover and account receivable turnover there no significant effect on the level of liquidity and the result simultaneous test showed cash turnover and account receivable turnover significant effect the level liquidity.
\end{abstract}

Keywords: Accounts Receivable Turnover, Cash Turnover, Liquidity

\begin{abstract}
ABSTRAK
Perusahaan yang tidak dapat mengendalikan likuiditas dengan baik dapat kehilangan keyakinan dari pihak eksternal. Perputaran kas adalah kemampuan perusahaan dalam memperolehkan kas atau keuntungan sehingga dapat membantu pihak manajemen dapat mengelola kas dengan baik. Perputaran piutang merupakan untuk mengetahui seberapa sering perputaran piutang usaha dalam mengubah kas usaha dalam waktu tertentu. Tujuan utama dari penelitian untuk melihat adakah pengaruh yang signifikan antara perputaran kas dan perputaran piutang baik itu parsial maupun simultan terhadap tingkat likuiditas, sehingga dapat dijadikan bahan pertimbangan bagi para pengusaha. Teknik pengumpulan sampel ini menggunakan purposive sampling dengan penentuan sampel nilai tertimbang tertentu agar data yang digunakan memiliki nilai yang lebih representatif sehingga sampel dapat mewakili bagian dari keseluruhan populasi. Data yang digunakan dalam penelitian ini data kuantitatif yang berupa sumber data sekunder dengan dengan mengumpulkan data laporan perusahaan dari tahun 2014 hingga 2018 populasi pada penelitian ini adalah 60 sampel. Penelitian ini menggunakan metode analisis data regresi linier berganda sehingga dapat menghasilkan pengolahan data berupa tabel maupun grafik dan kesimpulan. Dari hasil SPSS menunjukkan bahwa secara parsial perputaran kas dan perputaran piutang tidak terdapat pengaruh signifikan terhadap tingkat likuiditas dan hasil Uji $F$ menunjukkan secara simultan perputaran kas dan perputaran piutang berpengaruh signifikan terhadap tingkat likuiditas.
\end{abstract}

Kata Kunci: Perputaran Kas, Perputaran Piutang, Likuiditas 


\section{PENDAhUluan}

Pada saat pendirian perusahaan, secara garis besar setiap pengusaha memiliki harapan yang sama agar perusahaannya mendapatkan keuntungan atau laba yang semaksimal mungkin karena tanggungjawab perusahaan bukan hanya sebatas individu melainkan kepada seluruh pemegang saham. Di samping menghadapi persaingan yang ketat perusahaan juga harus dapat mengolah dan meneruskan perusahaan secara efesien dan efektif. Dalam perusahaan terdapat salah satu manfaat manajemen yang paling utama dalam menjalankan usaha adalah posisi manajemen keuangan, karena pihak manajemen dapat menjaga keseimbangan keuangan perusahaan agar dalam menjalankan kegiatan perusahaan tidak terjadi kekurangan dana sehingga dapat menjaga kelangsungan hidup perusahaan. Jika perusahaan mampu membayar utang jangka pendek pada saat jatuh tempo bisa dikatakan perusahaan dalam posisi keadaan lancar, sebaliknya apabila perusahaan dalam posisi tidak dapat membayar hutang jangka pendek dengan tepat waktu dapat diartikan perusahaandalam kondisi tidak lancar. Apabila perusahaan-yang tidak dapat mengendalikan likuiditas dengan baik dapat berdampak negatif bagi pihak eksternal perusahaan dan bisa menurunkan kemampuan perusahaan dalam mengembangkan perusahaannya serta juga kehilangan kepercayaan dari para supplier maupun investor. Pada tahun 2014 industri galangan kapal di Batam mulai memburuk ratusan perusahaan industri galangan kapal yang tutup dan beralih ke lokasi tempat lain. Hal ini terjadi dikarenakan banyak faktor antara lain permintaan pemesanan kapal semakin menurun, adanya persaingan yang pesat, dan bayaran upah karyawan yang tidak cukup sehingga banyak perusahaan saling membanting harga dan ribuan karyawan yang bekerja di industri galangan kapal terancam pemutusan hubungan kerja (PHK) hal ini menyebabkan mengapa banyak industri galangan kapal memilih untuk tutup dan beralih ke lokasi tempat lain. Dari sudut pandang perbankan perusahaan yang tidak dapat memenuhi kualifikasi pinjaman dana dari bank maka pihak bank tidak dapat memberikan pinjman dana. Dalam menjalanin usaha bisnis jual beli hal yang paling penting itu adalah umpan balik jika hanya satu pihak yang memberikan produk tetapi pihak yang menerima produk tidak memenuhi kewajiabnya untuk membayar maka lama kelamaan pihak yang memberi produk juga akan bangkrut karena menjalanin usaha butuh modal. Oleh sebab itu pentingnya potensial bagi penilaian perusahaan dalam dunia usaha baik dalam mengembangkan perusahaannya maupun menjaga kelangsungan hidup perusahaannya. Tidak hanya yang terjadi krisis ekonomi pada bidang pergalangan kapal namun perekonomian di Batam jadi lemah dari badan usaha Perseroan Terbuka hingga restoran tempat makan juga menjadi sepi, karena kurangnya penghasilan dari masyarakat yang karena pemutusan hubungan kerja (PHK) maka berkuranglah minat para masyarakat untuk belanja maupun makan restoran. Peneliti melakukan penelitian di perusahaan ini karena peneliti mengetahui terdapat beberapa masalah mengenai perputaran kas, perputaran piutang, terhadap likuiditas. Perputaran kas sebagai indikasi cepatnya kembali modal usaha yang tertanam pada kas atau bank melalui penjualan maupun pendapatan yang dihasilkan dalam satu masa tertentu sedangkan rasio perputaran piutang menunjukkan berapa lama masa penagihan piutang dagang kepada konsumen dalam jangka yang telah disepakati. Namun untuk menilai kesehatan keuangan perusahaan tidak hanya melihat dari tingkat rasio likuiditas melainkan juga harus melihat dari posisi rasio perputaran 
kas dan rasio perputaran piutang yang dapat mengakibatkan potensial perusahaan dalam pembayaran utang lancar menurun dan penghasilan perusahaan mengalami penurunan sehingga perkembangan usaha menjadi terbatas.

\section{KAJIAN LITERATUR}

\subsection{Likuiditas}

Likuiditas adalah sebagai pengukuran potensial suatu perusahaan untuk melunasi utang usaha yang sifatnya akan segera jatuh tempo sesuai dengan masa yang telah disepakati sebelumnya, yang masa jatuh tempo tidak lebih dari satu tahun. Rasio likuiditas ini biasanya digunakan untuk mengetahui tingkat kelancaran suatu perusahaan dalam melunasi utang usaha yang akan segera jatuh tempo. Setiap penyaluran produk baik dalam bentuk fisik maupun non fisik kepada konsumen tujuan utamanya jelas untuk mendapatkan keuntungan yang berlipatan, disamping menyalurkan produknya kepada konsumen sebaiknya pihak supplier harus mengetahui terlebih dahulu kondisi perusahaan yang akan disalurkan produk dan metode pembayaran piutang atas penyaluran produknya sehingga tidak terjadi perselisihan dikemudian hari. Pentingnya rasio likuiditas bagi perusahaan dapat menunjukkan sejauh mana kemahiran sebuah perusahaan untuk mengatasi utang usaha dalam membayar utang jangka pendek pada tepat waktu agar tidak terjadi hambatan bagi perusahaan dalam memperoleh keuntungan dari potongan pembelian dan secara tidak langsung mendapatkan kepercayaan dari pihak supplier sehingga dapat menjaga hubungan yang baik antara perusahaan dan supplier.

Fahmi (2017) menyatakan rasio ini adalah alat untuk mengukur segi tingkat kemampuan perusahaan dalam membayar utang usaha yang bersifat utang lancar yang akan segera jatuh tempo. Seperti membayar tagihan listrik, telepon, air, gaji teknisi, gaji karyawan pegawai dan kebutuhan usaha lainnya. Rasio likuiditas dalam bahasa asing dikenal sebagai short term liquidity. Ketidakmampuan perusahaan dalam membayar kewajiban lancar akan mempengaruhi pertumbuhan perusahaan pada periode kedepannya, dan hal ini akan menjadi sebuah masalah yang paling ekstrem bagi pemilik usaha. Dalam menghadapi kendala keuangan perusahaan, sebaiknya pihak manajemen dapat mencari faktor utama yang menyebabkan aliran dana perusahaan menjadi lambat mungkin dari segi penjualan karena omzet penjualan perusahaan yang menurun atau penerimaan kas atau bank yang kurang efektif karena para konsumen tidak membayar piutang usaha sehingga mengakibatkan aliran dana tersebut menjadi lambat. Sedangkan Siregar (2016) menjelaskan likuiditas adalah salah satu kunci yang dapat menentukan kesuksesan atau kegagalan pada sebuah perusahaan atau lembaga.

Suartini \& Sulistiyo (2017) menyatakan rasio likuiditas adalah rasio yang mengindikasikan kemahiran sebuah perusahaan dalam membayar utang jangka pendek usaha dengan masa yang telah ditentukan kurang dari satu tahun. Secara umum, periode jangka pendek kurang dari satu tahun dalam siklus operasional perusahaan.

Menurut Subramanyam \& Wild (2010), likuiditas (liquidity) merupakan suatu indikator yang dapat menilai tingkat kemampuan perusahaan dalam melunasi utang usaha dengan waktu yang telah disepakati. Tingkat likuiditas akan mempengaruhi operasional usaha dalam jangka panjang, menurunnya rasio likuiditas akan mempengaruhi pendapatan perusahaan karena mempengaruhi siklus pembayaran kepada distributor menjadi lambat secara langsung para distributor akan mempertimbangkan pemberian utang usaha dan penyaluran produk baik bentuk fisik maupun non fisik.

Untuk menghitung tingkat likuiditas perusahaan dalam membayar kewajiban lancar dapat diukur melalui dengan beberapa rumus yang dapat mengukur 
tingkat rasio likuiditas dalam penelitian ini membutuhkan laporan neraca dan laporan laba rugi sebagai data pendukung untuk mendapatkan rasio yang akan diolah adalah berikut ini:

Current Ratio $=\frac{\text { Aktiva Lancar }}{\text { Hutang Lancar }}$

\section{Rumus 1. Rasio Lancar}

\subsection{Perputaran Kas}

Kas merupakan aset perusahaan yang paling lancar dalam bentuk serangkaian dana untuk mempertahankan profitabilitas perusahaan yang digunakan untuk membiayai kebutuhan operasional perusahaan atau melakukan investasi baru dalam aset tetap. Kas dan bank yang tersedia dapat dibutuhkan dalam kebutuhan perusahaan terutama kebutuhan yang mendesak, selain mencakup kewajiban jangka pendek kepada distributor perusahaan dapat membiayai kegiatan operasional secara langsung oleh karena itu tidak terdapat kesulitan dalam mempertahankan profitabilitas perusahaan. Karena likuiditas adalah komponen yang paling likuid dari modal kerja, tanpa adanya kas dan bank yang tersedia baik diperusahaan maupun di bank perusahaan tidak dapat membayar gaji karyawan dan memenuhi kewajiban jangka pendek yang masa jempo kurang dari satu tahun, bahkan pembelian secara tunai yang dapat menguntungkan bagi perusahaan. Perusahaan dapat terjadi gagal karena kekurangan kas dan bank baik di perusahaan maupun di bank dapat terjadi kesulitan dalam menjalankan kegiatan operasional maupun pembayaran baik jangka pendek maupun jangka panjang kepada kreditor.

Menurut Gusti Ayu Purnamawati (2017), kas juga merupakan unsur utama modal kerja tingkat yang paling jenjang likuiditas dalam suatu perusahaan, disamping menjalankan bisnis usaha pihak manajemen perusahaan harus mengelola kas dan bank perusahaan dengan seimbang agar jumlah kas dan bank yang di perusahaan tidak terlalu banyak dan terlalu sedikit. Banyaknya kas dan bank diperusahaan merupakan hal yang baik bagi para kreditor dalam melunasi utang usaha namun jika dari sudut pandang pemilik perusahaan hal ini kurang baik karena pihak manajemen tidak menggunakan kas dan bank secara efektif dan efesien, mungkin digunakan dalam untuk menambah aset, menginvetasi yang dapat menguntungkan dengan laba yang maksimal. Perputaran kas adalah alat pengukuran berapa kali berputarnya kas yang dapat berubah menjadi kas dan bank perusahaan kembali dalam periode akuntansi, untuk mengetahui tingkat kecukupan modal usaha pada perusahaan. Semakin sering arus kas berputar, maka rasionya akan lebih tinggi dan keuangan perusahaan akan lebih likuid. Dari sudut pandang kreditor, perusahaan yang memiliki kas dan bank yang cukup akan meningkatkan siklus pembayaran yang baik dan distributor penuh dengan kepercayaan dalam menyalurkan produk atau jasa baik bentuk fisik maupun non fisik kepada supplier, dana kreditor yang dipinjam dari perusahaan dapat dijamin dengan aset yang relatif lebih lancar.

Perputaran kas juga merupakan potensial perusahaan dari segi memperolehkan pendapatan sehingga pihak manajemen mampu mengelola kas dengan baik dan tepat secara efektif dan efesien. Secara keseluruhan rasio ini dapat digunakan untuk mengindikasi kecepatan perubahan kas kembali menjadi aset, secara langsung pembayaran utang usaha baik itu jangka panjang maupun jangka pendek dan biaya atau beban yang berkaitan dengan operasional perusahaan dapat dilunasi pada tepat waktu. Banyaknya uang tunai usaha yang tersedia di dalam perusahaan dan pihak manajemen keuangan harus bisa mengendalikan keuangan perusahaan dengan tepat agar tidak disalahgunakan. Apabila kas perusahaan yang menganggur terlalu banyak sedangkan pengunaan kas atau bank perusahaan kurang efektif dalam mengelola kas atau bank perusahaan akan terjadi kas atau bank dalam perusahaan 
yang tersedia itu semakin tinggi oleh karena itu, sebuah perusahaan membutuhkan manajemen keuangan dalam pengendalian kas dan bank yang ada diperusahaan dan pengolahan keuangan perusahaan yang efektif dan efesien dalam menginvestasi maupun pembelian aset yang dapat menguntungkan bagi perusahaan (Hidayat, 2018).

Menurut Indriani Susantri (2019), perputaran kas merupakan rasio yang dapat menilai potensial suatu perusahaan dalam rangka melunasi utang yang akan segera jatuh tempo dengan ketersediaan kas dan bank perusahaan. Dan menurut Yuniati (2018), dari segi penjualan perputaran kas dapat menilai tingkat volume penjualan perusahaan dalam waktu tertentu secara langsung potensial perusahaan dalam melakukan pembayaran uatag jangka pendek atau utang yang segera jatuh tempo juga meningkat hal ini akan mendapatkan nilai tambahan dari distributor dalam menyalurkan prouk atau jasa baik itu bentuk fisik maupun non fisik.

Berikut ini terdapat rumus untuk menghitung perputaran kas, untuk menghitung perputaran kas nilai dari penjualannya diambil dari laporan laba rugi yaitu pendapatan bersih dan rata-rata kas diambil dari laporan neraca.

$\begin{aligned} & \text { Perputaran } \\ & \text { Kas }\end{aligned}$
Rumus 2. Perputaran Kas

Rumus 2. Perputaran Kas

\subsection{Perputaran Piutang}

Setiap manajemen dalam perusahaan mempunyai tujuan utamanya yaitu bagaimana meningkatkan penjualan perusahaan dalam satu periode, agar dapat memperoleh keuntungan yang sebesar mungkin bagi perusahaan. Salah satu metode dalam mempertahankan para konsumen atau mendapatkan konsumen yaitu dengan metode penjualan secara kredit atau piutang dagang kepada konsumen, dari sisi penjualan omzet penjualan perusahaan itu meningkat secara otomatis piutang usaha juga meningkat pada perusahaan tergantung pihak manajemen yang menentukan kebijakan berapa jangka waktu dalam pemberian utang pada saat penjualan secara kredit agar tidak terjadinya piutang tidak tertagih atau bad debt. Perputaran piutang akan menunjukkan berapa kali piutang dagang dapat tertagih dan kembali ke dalam kas perusahaan pada periode tertentu.

Menurut Dunia (2013), menjelaskan bahwa perputaran piutang merupakan ukuran efektivitas suatu perusahaan yang dinyatakan berapa kali perputaran dalam satu periode secara rata-rata suatu perusahaan melakukan penagihan piutang dagang atau jasa yang telah diserahkan kepada konsumen. Menurut Libby, Libby, \& Short (2009) menyatakan bahwa perputaran piutang adalah perputaran piutang usaha yang mengambarkan berapa kali pada umumnya piutang usaha yang dicatat dan ditagih dalam satu periode. Penjualan kredit kepada konsumen akan menyebabkan resiko yang tinggi dalam penagihan piutang usaha yang tidak efektif, sehingga menyebabkan rasio perputaran piutang rendah. Rasio yang tinggi juga menunjukkan sebuah masalah dalam perusahaan, kemungkinan kebijakan perusahaan terlalu ketat sehingga kehilangan kesempatan dalam mencari keuntungan.

Jika para konsumen membeli produk atau jasa baik dalam bentuk fisik maupun non fisik secara tunai maka perusahaan akan kehilangan dana dengan jumlah yang banyak hal ini dapat menyebabkan kekurangan dana pada perusahaan maka secara logika seorang pengusaha tidak mungkin membeli produk atau jasa baik dalam fisik maupun non fisik secara tunai kecuali pembelian produk diluar negeri, dari pihak supplier luar negeri akan melakukan permintaan kepada konsumen harus membeli dengan tunai karena berhubungan dengan kepercayaan dan domisili perusahaan jika konsumen membutuhkan produk tersebut maka harus membeli dengan uang tunai. Hal ini sangat 
mempengaruhi konsumen yang ada pada perusahaan dan dapat mengurangi keminatan para konsumen untuk membeli produknya secara tunai, mengakibatkan omzet penjualan perusahaan mengalami penurunan dan menjadi hambatan bagi perusahaan dalam mengembangkan usaha perusahaan. Namun hal ini dapat diatasi oleh pihak manajemen penjualan dengan memperhatikan rasio piutang berputar dalam satu periode tertentu keadaan lancar atau tidak lancar sebelum menyalurkan produk atau jasa maka dari itu dibutuhnya kerjasama antara supplier dan konsumen terjadinya hambatan perputaran piutang karena banyaknya penyaluran produk kepada konsumen, oleh dari itu pihak manajemen penjualan dapat pertimbangkan penyaluran produk atau jasa kepada konsumen. Semakin tinggi rasio perputaran piutang dapat disimpulkan semakin lancar piutang usaha berputar, untuk menghitung perputaran piutang dilihat dari laporan laba rugi dan neraca yaitu dengan mengambil nilai penjualan kredit dibagi dengan nilai ratarata dari keseluruhan piutang untuk mendapatkan nilai rata-rata piutang, piutang awal bulan ditambah akhir bulan dibagi 2, dapat digunakan dengan rumus antara lain:

\begin{tabular}{|l} 
Perputaran \\
Piutang
\end{tabular}$=\frac{\text { Penjualan Kredit }}{\text { Rata-rata Piutang }}$

Rumus 3. Perputaran Piutang

\section{METODOLOGI}

\subsection{Desain Penelitian}

Desain penelitian (Reseacrh Design), adalah rancangan cetak biru (blue print) yang akan dilakukan oleh peneliti mengenai perumusan masalah, pengumpulan, pengukuran, pengolahan, dan menganalisis data untuk menjawab pertanyaan penelitian sehingga dapat tercapai tujuan penelitian (Indrawati, 2015).

\subsection{Populasi dan Sampel}

Populasi merupakan kumpulan dari bagian karakteristik maupun jumlah yang dapat berupa orang atau benda yang dapat disimpulkan dalam sebuah penelitian. Menurut Sugiyono (2012) mengungkapkan populasi adalah wilayah generalisasi yang meliputi obyek atau subyek yang memiliki mutu dan spesifik tertentu oleh peneliti untuk mengamati kemudian membuat kesimpulan. Dalam penelitian ini populasi yang digunakan sebanyak 60 catatan keuangan perusahaan PT. Citra Batam Millenium dari periode 2014 hingga periode 2018.

\subsection{Analisis Data}

Analisis data menggunakan analisis deskriptif, uji asumsi klasik yang berupa uji normalitas, uji multikolinearitas, uji heteroskedasititas, uji autokorelasi, analisis linear berganda, pengujian hipotesis yang berupa uji t, uji $\mathrm{F}$, dan yang terakhir uji koefisien determinasi (R2).

\section{HASIL DAN PEMBAHASAN}

\subsection{Statistik Deskriptif}

Dalam pengolahan data statistk deskriptif dapat menyajikan dalam berupa tabel maupun frekuensi, grafik yang berupa garis atau batang, diagram dan pistogram atau lingkaran, untuk mendapati nilai ratarata (mean), minimum, maximum, maupun standar deviasi nilai yang paling tinggi pada setiap variabel dari suatu pencarian.

\begin{tabular}{|c|c|c|c|c|c|}
\hline \multicolumn{6}{|c|}{ Tabel 1. Statistikik Deskcingif } \\
\hline & $\mathrm{N}$ & Minimum & Maximum & Mean & Std. Deviation \\
\hline Perputaran Kas & 60 & 19 & 50 & 2985 & .06208 \\
\hline Perputaran Piutang & 60 &, 12 & .57 & 2833 & 11468 \\
\hline Likuiditas & 60 & 30 &, 76 & ,5887 & , 10611 \\
\hline Valid N (listwise) & 60 & & & & \\
\hline
\end{tabular}

Pada table 1 menjelaskan hasil minimum, maksimum, nilai rata-rata (mean), dan standar nilai deviasi dari variabel perputaran kas, perputaran piutang, dan likuiditas. Bisa dilihat bahwa banyak data yang diolah adalah 60 data sampel dari laporan neraca dan laporan laba rugi periode 2014 hingga dengan 2018. Variabel perputaran kas mempunyai nilai standar deviasi 0,06208 dengan nilai 
terendah yaitu 0,19 dan angka maksimum menunjukkan 0,50 dengan nilai rata-rata yaitu 0,2985 . Varibel perputaran piutang memiliki standar deviasi 0,11468 dengan angka terendah 0,12 angka maksimum menunjukkan 0,57 dengan nilai rata-rata yaitu 2,833. Variabel likuiditas memiliki standar deviasi 0,10611 dengan nilai terendah 0,30 dengan angka maksimum menunjukkan 0,76 dengan nilai rata-rata 0,5887 .

4.2 Uji Asumsi Klasik

1. Uji Normalitas

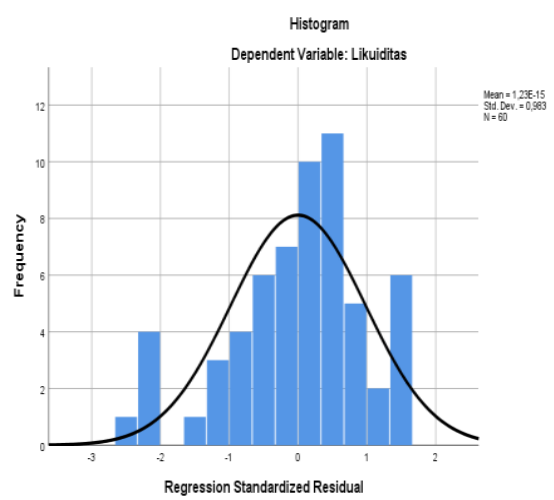

Gambar 1. Nilai Uji Histogram

Sumber: Hasil Pengolah SPSS 25

Hasil pengolahan data histogram diatas dapat disimpulakn bahwa gambar kurva yang dihasilkan dengan karakter lonceng (bell-shapped curve), maka bisa dinyatakan data yang diolah berdistribusi wajar atau normal. Karena didalam garis itu berbentuk melengkung seperti lonceng terbalik dan titik tertinggi pada garis tertinggi sejajar dengan 0 .

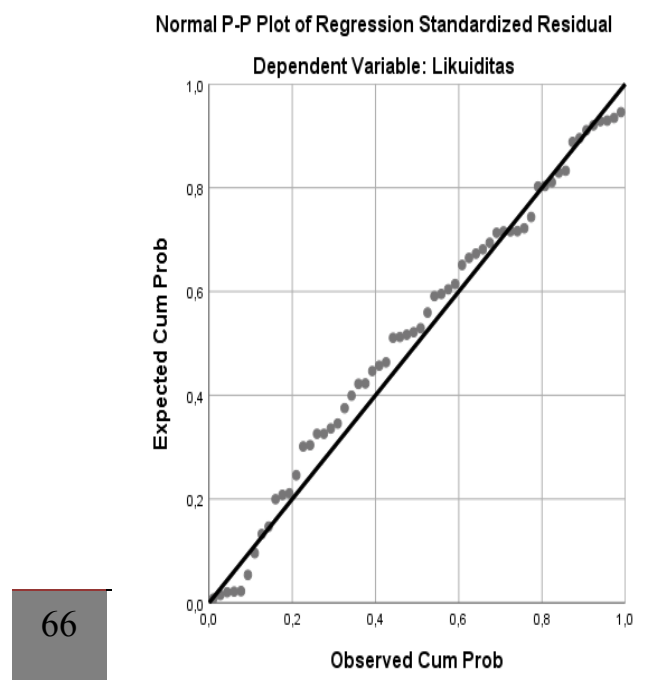

Gambar 2. Hasil Uji Normal P-Plot Sumber: Hasil Pengolah SPSS 25

Berdasarkan gambar yang disajikan normal p-plot dapat dilihat data yang menyebar berkisar menunjukkan diantara garis diagonal dan mengikuti jurus garis diagonal, maka dapat diartikan data yang diolah berdistribusi secara normal. Dalam menguji normalitas dapat dilakukan dengan menggunakan nilai KolmogorovSmirnov dilihat dari nilai probability sig (2 tailed) untuk mengetahui distribusi data dalam bentuk normal atau tidak dalam pengujian ini.

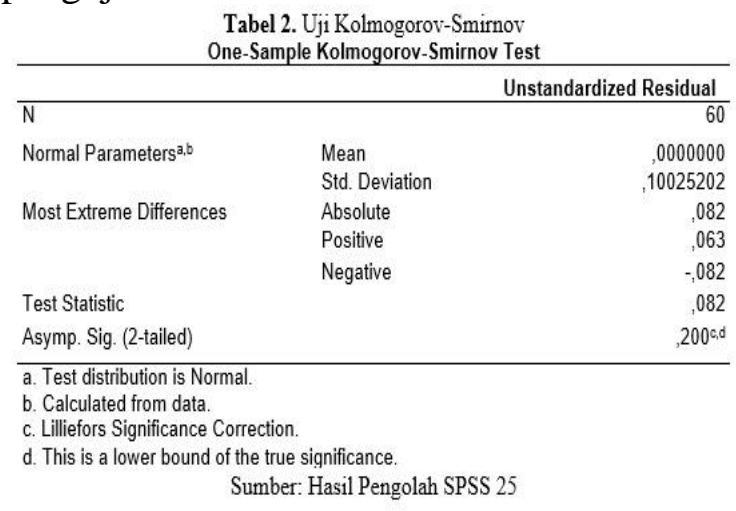

2. Uji multikolinearitas

Tabel 3. Uji Multikolinearitas

\begin{tabular}{|c|c|c|c|}
\hline \multirow[b]{2}{*}{ Model } & & \multicolumn{2}{|c|}{ Collinearity Statisitics } \\
\hline & & Tolerance & $V \mid F$ \\
\hline 1 & (Constant) & & \\
\hline & Perputaran Kas & & 1,01 \\
\hline & Perputaran Piutang & & 1,01 \\
\hline
\end{tabular}

Dari tabel 3 yang telah disajikan diatas seluruh variabel independen mengindikasikan angka tolerance lebih dari angka 0,1 sedangkan angka VIF lebih kurang dari 10, nilai tolerance variabel perputaran kas yaitu 0,985 dengan nilai VIF adalah 1,016. Angka tolerance variabel perputaran piutang yaitu 0,985 dan nilai VIF adalah 1,016. Dari hasil pengolahan output SPSS disajikan tidak terjadinya regresi antar variabel independen. 


\section{Uji Heteroskedastitas}

Tujuan melakukan pengujian heteroskedasititas ini, untuk melihat adakah ketidaksamaan dalam satu model regresi antara bentuk dari residual dari satu observasi ke observasi lainnya. Dalam penelitian ini pengujian menyajikan grafik scatterplot yang diolah dari program SPSS

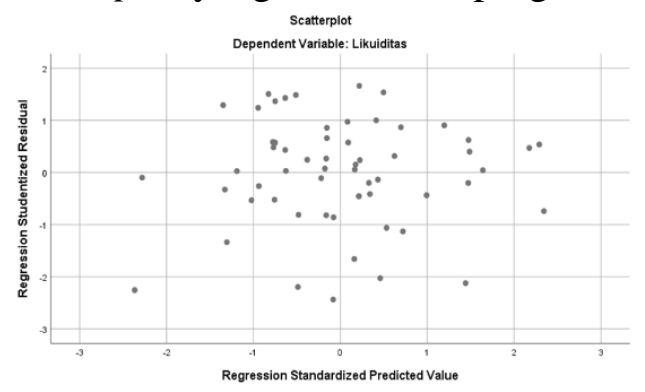

Gambar 3. Uji Heteroskedastisitas

Sumber: Hasil Pengolah SPSS 25

Dari gambar diatas hasil uji heteroskedasititas menggunakan scatterplot untuk menunjukkan bahwa terdapat titik yang penyebaran diatas dan dibawah angka 0 pada sumbu Y) maka dapat diartikan bahwa tidak terjadinya masalah heteroskedastisitas.

\section{Uji Autokorelasi}

Menurut Yudiaatmaja (2013), melakukan pengujian autokorelasi ini dilakukan untuk memperjelaskan suatu model regresi dalam penelitian adakah terdapat hubungan timbal balik antara variabel pengganggu dalam periode $t$ dengan pengganggu pada periode $\mathrm{t}-1$. Pengujian penelitian ini peneliti melakukan uji Durbin-Watson (DW test) untuk mengetahui adakah terjadinya autokorelasi negatif atau positif. Dari nilai Durbin-Watson terdapat angka 1,885 dan pada tabel Durbin-Watson jumlah sampel 60 (n) dengan jumlah variabel 3, sedangkan nilai Durbin-Watson pada regresi 1,885 . Besar nilai dl pada tabel 1,4797 dan du pada tabel 1,6889. Dengan melihat pedoman rumus Durbin-Watson bahwa nilai $\mathrm{du}<\mathrm{dw}<4$-du dengan nilai statistik $1,6889<2,252<2,311$, dari hasil pengujian dapat dilihat tidak terjadi autokorelasi pada penelitian ini. Hasil ini dapat dilihat dari tabel 4 yang ditampilkan dibawah.

\begin{tabular}{llllll}
\multicolumn{5}{c}{ Tabel 4. Hasil Lji Autoloorelasi } \\
Model Summary
\end{tabular}

\subsection{Uji Hipotesis}

\section{Uji T}

Menurut Chandrarin (c2017), pengujian uji $\mathrm{t}$ untuk mengetahui pengaruh variabel independen terhadap dependen. Uji ini menguji adakah terdapat signifikan terhadap setiap variabel independen yang secara parsial terhadap variabel dependen. Jika signifikan $\mathrm{t}<0$, bahwa hipotesis diterima, sedangkan apabila signifikan $\mathrm{t}>$ 0,05 tidak terjadi pengaruh signifikan secara parsial maka hipotesis ditolaDiketahui $t_{\text {tabel }}$ pada tabel signifikan $0,05 / 2=0,025$ (uji 2 sisi) dengan derajat kebebasan $\mathrm{df}=\mathrm{n}-\mathrm{k}-1$ atau $60-2-1=57$.

\begin{tabular}{lccccc}
\multicolumn{7}{c}{ Tabel 5. Ujit } \\
\hline \multicolumn{7}{c}{$\begin{array}{c}\text { Unstandardized } \\
\text { Coefficients }\end{array}$} & $\begin{array}{c}\text { Standardized } \\
\text { Coefficients }\end{array}$ \\
Model & B & Std. Error & Beta & $t$ & Sig. \\
\hline 1 (Constant) &, 652 &, 070 & & 9,332 &, 000 \\
Perputaran Kas &,- 427 &, 216 & -250 & $-1,981$ &, 052 \\
Perputaran &, 227 &, 117 &, 245 & 1,944 &, 057 \\
Piutang & & & & & \\
\hline
\end{tabular}

\section{a. Dependent Variable: likwoditas}

Sumber: Hasil Rennolahan SPSS 25

Diketahui $t_{\text {tabel }}$ pada tabel signifikan $0,05 / 2=0,025$ (uji 2 sisi) dengan derajat kebebasan $\mathrm{df}=\mathrm{n}-\mathrm{k}-1$ atau $60-2-1=57$. Berdasarkan nilai tabel 4.6 maka dapat menjelaskan sebagai berikut:

1. Perputaran Kas terhadap Likuiditas

Variabel Perputaran Kas ( $\left.\mathrm{X}_{1}\right)$ mempunyai perhitungan signifikan dengan $0,052>0,05$ maka dapat dinyatakan Ho diterima Ha ditolak. Hal tersebut dapat diartikan tidak terjadi 
pengaruh secara parsial antara variabel perputaran kas terhadap likuiditas. Dengan menggunakan derajat kebebasan (df) thitung memiliki nilai 0,052 sehingga $t_{\text {tabel }} 2,00247>-1,981$ dan memiliki nilai signifikan sebesar 0,052. Dari hasil yang telah diuji diatas secara singkat dapat menyimpulkan hipotesis pertama ditolak atau perputaran kas tidak terjadinya pengaruh yang signifikan secara parsial terhadap likuiditas.

2. Perputaran Piutang terhadap likuiditas Variabel Perputaran Piutang $\left(\mathrm{X}_{2}\right)$ memiliki nilai signifikan dengan 0,057 $>$,005 yang dinyatakan Ha diterima Ho ditolak. Hal tersebut dapat menyimpulkan terjadinya pengaruh secara parsial antara variabel perputaran piutang terhadap likuiditas. Dengan menggunakan derajat kebebasan (df) $t_{\text {hitung }}$ terdapat nilai 0,057 sehingga $t_{\text {tabel }}$ $2,00247>1,944$ dan tidak memiliki nilai signifikan. Dari hasil pengolahan diatas dapat menarik kesimpulan secara umum hipotesis kedua Ho diterima $\mathrm{Ha}$ ditolak atau perputaran piutang secara parsial tidak berpengaruh signifikan terhadap likuiditas

\section{Uji F}

Data penelitian yang diolah dapatdiketahui df1=k-1 atau 3-1= df2 = n-k (banyak sampel) $60-2-1=57$, dari hasil $F_{\text {hitungl }} 3,428$. Hasil pengolahan output SPSS, angka $F_{\text {hitung }}$ adalah 3,428 dan nilai likuiditas signifikan adalah 0,039 nilai $F_{\text {hitung }} 3,428>3,16$ dan hasil signifikan $0,039<0,05$ dari penjelasan diatas dapat dijelaskan Ha diterima Ho ditolak, tabel diatas membuktikan bahwa variabel perputaran kas dan variabel perputaran piutang terjadinya pengaruh signifikan secara bersamaan terhadap likuiditas.

\begin{tabular}{|c|c|c|c|c|c|c|}
\hline \multicolumn{7}{|c|}{$\begin{array}{c}\text { Tabel 6. UjiF } \\
\text { ANOVAa }\end{array}$} \\
\hline \multicolumn{2}{|c|}{ Model } & $\begin{array}{l}\text { Sum of } \\
\text { Squares }\end{array}$ & df & Mean Square & $\mathrm{F}$ & Sig. \\
\hline \multirow[t]{3}{*}{1} & Regression &, 071 & 2 & 036 & 3,428 &, $039^{6}$ \\
\hline & Residual & 593 & 57 &, 010 & & \\
\hline & Total & 664 & 59 & & & \\
\hline \multicolumn{7}{|c|}{ a. Dependent Variable: Likuiditas } \\
\hline & & Sumber: $\mathrm{H}$ & & an SPSS 25 & & \\
\hline
\end{tabular}

4.4 Koefisien Determinasi

Dalam penelitian koefisien determinasi tabel 4.8 yang disajikan bisa dinyatakan angka Adjusted $R$ Square adalah 0,076 artinya persentase variabel perputaran kas $\left(\mathrm{X}_{1}\right)$, perputaran piutang $\left(\mathrm{X}_{2}\right)$ dalam penelitian model regresi ini $7.6 \%$. Persentase variabel independen adalah $7.6 \%$ dan persentase yang tersisa adalah $92.4 \%(100 \%-7.6 \%)$.

\begin{tabular}{|c|c|c|c|c|c|}
\hline \multicolumn{6}{|c|}{$\begin{array}{l}\text { Tabel 7. Uji Koefisien Determinasi } \\
\text { Model Summary }{ }^{b}\end{array}$} \\
\hline Model & \multirow{2}{*}{$\frac{R}{328^{3}}$} & \multirow{2}{*}{\multicolumn{2}{|c|}{$\begin{array}{c}\begin{array}{c}\text { Adjusted R } \\
\text { Square }\end{array} \\
076\end{array}$}} & $\begin{array}{l}\text { Std. Error of the } \\
\text { Estimate }\end{array}$ & Durbin-Watson \\
\hline 1 & & & & ,10200 & 1,885 \\
\hline \multicolumn{6}{|c|}{ a. Predictors: (Constant), Perputaran Piutang, Perputaran Kas } \\
\hline \multicolumn{6}{|c|}{ b. Dependent Variable: Likuiditas } \\
\hline & & Sumber: & IPengolaha & $\operatorname{PSS} 25$ & \\
\hline
\end{tabular}

\section{SIMPULAN DAN SARAN}

Perusahaan manajemen harus dapat menjaga tingkat likuiditas maupun mengontrol keuangan penerimaan kas dan pengeluaran kas sehingga kas perusahaan dapat digunakan lebih efesiensi karena tingkat likuiditas semakin baik akan menarik kepercayaan dari para investor yang ingin berinvestasi diperusahaannya agar perusahaan mendapatkan tambahan modal usaha sehingga perusahaan dapat mengembangkan usahanya lebih baik karena kas merupakan modal kerja perusahaan. Bagi para investor agar dapat memperhatikan faktor-faktor yang menyebabkan penurunan likuiditas pada sebuah perusahaan sebelum menginvestasi karena turunnya tingkat likuiditas perusahaan dapat dipengaruhi oleh banyak faktor salah satunya ialah omzet penjualan kredit meningkat secara langsung piutang usaha juga meningkat sedangkan 
pengembalian kas perusahaan menurun dan menyebabkan terjadinya ketidakseimbangan antara pemasukan kas atau bank dan pengeluaran kas sehingga menyebabkan penurunan potensial perusahaan dalam membayar kewajiban jangka pendek.

\section{DAFTAR PUSTAKA}

Chandrarin, G. (2017). Metode Riset Akuntansi. Jakarta Selatan: Salemba Empat.

Dunia, F. A. (2013). Pengantar Akuntansi. Jakarta: Lembaga Penerbit.

Fahmi, I. (2017). Analisis Laporan Keuangan. Bandung: Alfabeta.

Gusti Ayu Purnamawati, I. (2017). Manajemen Keuangan. Depok: PT. Rajagrafindo Persada.

Hidayat, R. (2018). Pengaruh Perputaran Kas dan Perputaran Piutang Terhadap Tingkat Likuiditas pada Perusahaan Otomotif yang Terdaftar di Bursa Efek Indonesia. Jurnal Akuntansi, 4(2).

Indrawati, P. . (2015). Metode Penelitian Manajemen Dan Bisnis. Bandung: PT. Refika Aditama.

Indriani Susantri, H. (2019). Pengaruh Perputaran Kas, Modal Kerja dan Perputaran Piutang terhadap Likuiditas pada Perusahaan Consumer Goods yang Terdaftar di Bursa Efek Indonesia Periode 20142017. Jurnal Akuntansi, 13(1), 95.

Libby, R., Libby, P. A., \& Short, D. G. (2009). Akuntansi Keuangan. Yogyakarta: Andi.

Siregar, Q. R. (2016). Pengaruh Perputaran Persediaan dan Perputaran Piutang terhadap Likuiditas pada Perusahaan Otomotif yang Terdaftar di Bursi Efek Indonesia Periode 2010-2013. Jurnal Akuntansi, 17.

Suartini, S., \& Sulistiyo, H. (2017). Analisis Laporan Keuangan. Jakarta: Mitra Wacana Media.

Subramanyam, K. R., \& Wild, J. J. (2010). Analisis Laporan Keuangan. Jakarta:
Salemba Empat.

Sugiyono, D. (2012). Metode Penelitian Kuantitatif, Kualitatif dan $R \& D$. Bandung: Alfabeta.

Yudiaatmaja, F. (2013). Analisis Regresi. Jakarta: PT. Gramedia Pustaka Utama.

Yuniati, S. (2018). Pengaruh Perputaran Piutang dan Perputaran Kas Terhadap Likuiditas di CV. Sinar Karya Pekanbaru. Jurnal Akuntansi, 2. 